\title{
Lê Quý Đôn's Theory of Li-qi
}

\author{
Yueh-hui LIN*
}

\begin{abstract}
This paper discusses the work of Lê Quý Đôn (1726-1784), a prominent scholar of Later Lê Vietnam who was deeply influenced by Song-Ming Neo-Confucianism. Lê's masterwork, the Classified Discourses from Yun Terrace (Yuntai leiyu 芸臺類語, Vân đài loại $n g \tilde{u})$, exemplifies this intellectual heritage. This essay considers the text's first volume in light of Zhu Xi's theory of li-qi. While drawing deeply from Zhu Xi's theory of an inseparable $l i$-qi, Lê's concept of $l i$-qi ultimately originated in Han dynasty $q i$-transformative cosmology. Also influenced by a Vietnamese tradition of Three Teachings syncretism, Lê integrated Neo-Confucianism with Han cosmology to create a unique $l i$-qi theory.
\end{abstract}

Keywords: Zhu Xi, Lê Quý Đôn, Vietnamese Confucianism, li-qi theory, Yuntai leiyu (Vầ đài loại ngũu)

\section{Lê Quý Đônova teorija li-qi}

\section{Izvleček}

Članek obravnava delo priznanega učenjaka Lê Quýja Đôna (1726-1784) s konca vietnamske dinastije Le, na katerega je močno vplivalo neokonfucijanstvo dinastij Song in Ming. Ta idejna zapuščina se kaže v Lejevem mojstrskem delu Razvrščene razprave iz terase Vinske rutice (Yuntai leiyu 芸臺類語, Vân đài loại ngũu). Članek obravnava prvi zvezek tega dela, in sicer na podlagi Zhu Xijeve teorije o liju in qiju. Čeprav je Lê Quý Đôn izhajal iz Zhu Xijeve teorije o neločljivosti lija in qija, Lejev koncept lija in qija izvira iz transformativne kozmologije, ki se je razvila v dinastiji Han. Le je pod vplivom vietnamske tradicije sinkretizma Treh naukov neokonfucijanstvo povezal s hansko kozmologijo ter ustvaril edinstveno teorijo lija in qija.

Ključne besede: Zhu Xi, Le Quy Don, konfucijanstvo v Vietnamu, teorija li-qi, Yuntai leiyu (Vân đài loại ngũu)

\footnotetext{
* Yueh-hui LIN (林月惠), PhD, Research Fellow, Institute of Chinese Literature \& Philosophy, Academia Sinica (R.O.C) (中央研究院中國文哲研究所). Email address: linyh@gate.sinica.edu.tw
}

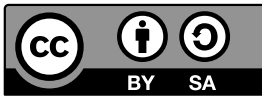




\section{Introduction}

Confucianism has long been important within Chinese culture, exerting a deep influence upon the societies of traditional China. But from the 12th century onward, Neo-Confucianism became not only the intellectual mainstream in China, but also a representative of East Asian civilization as a whole and a common intellectual resource within the Sinograph cultural sphere. ${ }^{1}$ Noteworthy here is the process of introducing Zhu Xi's thought into the regions bordering China to the east and south. In the east, Neo-Confucianism was introduced to Korea in the fourteent century, and exercised a dominant influence on the politics and culture of the Joseon dynasty (1392-1910). Neo-Confucianism was also introduced early on to Japan, and its influence pervaded the Tokugawa period (1603-1868). To the south, Neo-Confucianism spread to Vietnam and profoundly impacted the Later Lê (1428-1784) and Nguyễn dynasties (1802-1945), leading to what is widely seen as the golden age of Vietnamese Confucianism. The diversity of East Asian Confucianism makes it clear, however, that Neo-Confucianism, expanding eastward and southward, not only planted deep roots in Korea, Japan and Vietnam, but was also indigenized and transformed in all three countries, becoming essential aspects of each society's cultural heritage.

The history of exchange between China and Vietnam began with Qin Shihuang's suppression of Lingnan 嶺南 in 214 BC. Qin Shihuang subsequently established three commanderies in what is now Northern Vietnam and South China: Guilin 桂林, Xiang 象, and Nanhai 南海. The Xiang commandery is thought to be consisted of what are today the northern and central regions of Vietnam. This marked the beginning of a system of commanderies and prefectures that enabled China's subsequent colonization of Vietnam. Subsequently, the Han dynasty reorganized the territory into the Jiaozhi 交趾部 (Giao Chi) region; in the Three Kingdoms period, the Eastern Jin and Southern dynasties established Jiaozhou (Giao Châu 交州), while the Tang dynasty created the Annan 安南 (An Nam) Protectorate General (安南都 護府 An Nam Đô Hộ Phủ). For approximately a millennium—-from the Qin-Han period to the Late Tang - Vietnam was a commandery of China. Vietnamese today refer to the period as "the Northern colonization" or "the period of domination".

1 Tu Weiming, following Mou Zongsan's theory, proposed three periods of Confucianism, writing: "The 'three periods of Confucianism' can be summarized as follows. From the pre-Qin era until when Confucianism had developed into one of the main currents of Chinese thought; that is the first period. The second one began when Confucianism progressively became representative of East Asian civilization at large after its renaissance in the Song dynasty. And the third period was from the First Sino-Japanese War (1895) and the May Fourth Movement (1919) onward." (Tu 2002, 603) Chen Lai also affirmed that "Neo-Confucianism is the common manifestation of the East Asian civilization" (Chen 2008, 2). 
Starting with the Song, Vietnam recovered its independence and established its own feudal royal dynasties, all while nominally an outlying vassal country in relation to China. In reality, Vietnam had largely escaped Chinese domination and achieved independence. The successive dynasties of independent Vietnam were the Đinh dynasty (968-980), Early Lê dynasty (980-1009), Lý dynasty (1010-1225), Trần dynasty (1225-1440), and Hồ dynasty (1400-1407). After a short period under Ming Chinese domination (1414-1427), Vietnam again established a new dynasty, the Later Lê (1428-1788), the longest-lasting dynasty in Vietnamese history. In 1788, Nguyễn Huệ came to the throne, establishing the Tây Sơn dynasty (1788-1802). Subsequently Nguyễn Phúc Ánh became king, establishing the Nguyễn dynasty (1802-1945), the last feudal dynasty in Vietnamese history. In the late years of the Nguyễn, under the coercion of Western powers, Vietnam finally became a protectorate of France in 1885 (Yu and Tan 2005, 40-49).

Vietnamese dynasties were deeply influenced by Chinese, particularly Confucian, administrative and political models. Much like China, Vietnamese dynasties established systems of competitive examinations to select scholar-officials, eventually using the Confucian Four Books (四書) and Five Classics (五經) as official textbooks. In the Lý dynasty (1010-1225), a Confucian Temple of Literature, or Wenmiao (文廟, Văn Miếu), was built in the capital Thăng Long in 1070; examinations were organized in 1075; an Imperial College (國子監, Quốc Tử Giám) was founded in 1076; and a Vietnamese Hanlin Academy 翰林院 was established in 1086; but the examination system remained at a preliminary stage until the later years of the dynasty, with examinations held only sporadically. Additionally, under the Lý dynasty all three major teachings (Confucianism, Buddhism, and Daoism) developed together, and among them Buddhism enjoyed the position of dominant ideology at the Lý court and became the main current of cultural life.

Succeeding the throne, the Trần dynasty (1225-1440) formally chose Confucianism as the official ideology and created a comprehensive education system, with central and local state-run and private schools. In addition, the Trần examination system was reformed, with Confucian classics serving as the exams' base texts. These policies were retained by successive Vietnamese dynasties. Thanks to the development of both state and private education and the examination system, the number of Confucian scholars rapidly increased, and their important roles in the royal court, in turn, promoted the prestige of Confucianism. In 1370, the leadership of the Trần dynasty took the memorial tablet of Chu Văn An 朱文安 (d. 1370), the master of Vietnamese Confucianism, to the Wenmiao for worship alongside other Confucian sages, indicating the high status Confucianism attained in that period. 
The succeeding Lê dynasty became not only Vietnam's longest-lasting dynasty, but also the most vibrant period for Confucianism, analogous to China's MingQing period. The Later Lê kings revered Confucianism, taking it as their leading statecraft theory, the theoretical basis for their policies, and as an ethical system for kings, mandarins and commoners alike to follow. Confucius was apotheosized and Confucianism elevated to the status of state religion.

The Vietnamese Confucianism of the Later Lê period was deeply influenced by orthodox Confucianism then prevalent in China, taking Zhu Xi's teachings as orthodoxy. Vietnamese Confucianism both maintained a speculative character and also emphasized practical and moral education. Confucianism consequently played an active role in maintaining social stability, receiving support from both the Later Lê rulers and the scholarly class. While Confucianism reigned supreme, Buddhism and Daoism were often restricted. Thanks to this official patronage, the Later Lê dynasty witnessed a continuous growth of the ranks of the Confucian scholars, among whom Nguyễn Trãi 阮廌 (1380-1442), Nguyễn Bỉnh Khiêm 阮秉謙 (1491-1585), Phan Phu Tiên 潘孚先 (1370-1482), Ngô Sĩ Liên 吳士 連 (around 1400-unknown), and the subject of this essay, Lê Quý Đôn 黎貴惇 (1726-1784), are considered the most outstanding figures. Confucianism maintained this position until the early and middle periods of the Nguyễn dynasty. However, due both to the ideological rigidity of Confucianism and the endogenous deficiencies of the examination system, Vietnam's 800-year old examination system was abolished in 1919. The efforts by French colonial authorities to romanize the writing system, eliminating the Chinese-derived Han and Nôm characters, resulted in it becoming difficult for Vietnamese to access classical Confucian texts. The Vietnamese grew increasingly critical of Confucianism, and opposition to Confucian thought grew in turn. From the late Nguyễn dynasty onwards, Confucianism fell into decline and gradually disappeared from the mainstream of Vietnamese history (He 2000, 334-80).

The Later Lê dynasty was thus the zenith of Vietnamese Confucianism, and, crucially, saw special attention paid to the publication of the Confucian classics. Scholars engraved and printed many editions of the Confucian texts, such as new editions of the 1435 Sishu daquan 四書大全 (Great Collection of the Four Books, Tư Thu Đại Toàn) and the Wujing daquan 五經大全 (Great Collection of the Five Classics, Ngũ Kinh Đại Toàn) that were provided to state schools in 1734. The system of examinations also contributed significantly to the improvement in status of the scholar-official class. In addition, Lê Thánh Tông 黎聖宗 (1442-1497; r. 1460-1497), traditionally regarded as one of the greatest Lê dynasty monarchs, enthusiastically promoted the Confucian virtue of ritual propriety (liyi 禮義, lễ nghĩa), encouraging “loyalty and faithfulness, filial piety and 
fraternal duty” (忠信孝悌, trung tín hiếu đễ). Emulating the laws of the Sui and Tang dynasties, he ordered the compilation of the "Hồng Đức Code" 洪德法典 to promulgate the "Twenty-four Teachings" (二十四條訓, Nhị thập tứ điều huấn), thereby allowing Confucian ethics to take deep root in all aspects of Vietnamese social life. Moreover, the practical morality that Neo-Confucianism emphasized was also publicized widely through popular cultivating activities.

Lê Quý Đôn, the Vietnamese Confucian scholar whose thought is the subject of this paper, was one of the most important Confucian figures of that era, and his life and thought reflect the flourishing academic atmosphere of the Late Lê. Lê Quý Đôn (courtesy name: Doãn Hậu 允厚; literary name: Quế Đường 桂堂) was born in Diên Hà 延河 District, Thái Bình Province 太平省. Descended from a scholarly family, by the end of his youth he had read the Four Books and Five Classics and various works of the baijia 百家, or Hundred Schools, and was already renowned for his comprehensive knowledge of Chinese studies. At the age of 27, he passed the imperial examination and was given the title Editor of the Imperial College (國 史館纂修) at Vietnam's Hanlin Academy (翰林院). Subsequently he was designated Lecturer of the Academy (翰林院侍講), Scholar of the Secretariat Council ( 秘書閣學士), and Governor (參政) of Hải Dương Province 海陽省. Between 1760 and 1762, Lê was sent to China as the King's envoy. During his time in China Lê travelled and observed widely, focusing his attention on Chinese politics in order "to understand how the politics of the upper nation runs and its people are" (Lê $n$. $d$., "Preamble"). In addition, he came into contact with many Chinese scholar-officials, and even met Joseon envoys, including Hong Kyehee 洪啟禧 (1703-1771). ${ }^{2}$

While maintaining an active political career, Lê also endeavoured to read, write, and teach disciples. He ranks among the most prolific authors of traditional Vietnam. His works are concerned with many different subjects, including literature, philosophy, economics, and history. ${ }^{3}$ Lê enjoyed, and continues to enjoy, a

2 The preface to Lê Quý Đôn's Shengmo xianfan lu (聖謨賢範錄, Thánh mô hiền phạm luc, Record of Saints' Models and Sages' Examples) was written by Hong Kyehee.

3 Lê Quý Đôn's prolific output includes: Sishu lüejie (四書略解, Tư thu voóc giải, Concise Interpretation of the Four Books), Shujing yanyi (書經衍義, Thu kinh diễn nghĩa, Commentary on the Classic of Documents), Yuntai leiyu (芸臺類語, Vân đài loại ngũ,, Classified Discourses from Yun Terrace), Qunshu kaobian (群書考辨, Quần thu khảo biện, Disquisition into Various Books), Yinzhi wenzhu (陰騭文注, Âm chất văn chú, Annotated Account of Secret Charity), Shengmo xianfan $l u$ (聖謨賢範錄, Thánh mô hiền pham luc, Record of Saints' Models and Sages' Examples), Jianwen xiaolu (見聞小錄, Kiến văn tiểu luc, Scrappy Notes Based on Observation), Li chao tongshi (黎朝通史, Lê triều thông sủ, Narrative History of the Le Dynasty), Guoshi xubian (國史續編, Quốc sử tục biên, National History Sequel), Bei shi tonglu (北使通錄, Bắc sứ thông luc, Records of a Diplomatic Trip to the North), Queduong shiji (桂堂詩集, Quế Đuòng thi tậ, Collection of Queduong's Poems), Quanyue shilu (全越詩錄, Toàn Việt thi luc, Toan Viet Poetry Collection), and Huangyue wenhai (皇越文海, Hoàng Việt văn hải, Literature Collection of Hoang Viet). 
high reputation; his disciple Bùi Tồn Am (裴存庵) praised him as “a master of remarkable intelligence and comprehensive knowledge, whose excellent works are popular today and will be handed down to posterity; in our country there is a figure like him only every 200 years” (Bui n. d., 5a). Ngô Thì Sĩ 吳時仕 (1726-1780), a Confucian scholar in the late Lê dynasty, also admired Lê, noting that "his literature is outstanding; he has passed three times at the first rank in examinations; his fame is widespread in two countries, and is a leader among the Confucians" (in Yu 2000, 199). This paper, as a matter of concision, will focus on the volume “ $L i$-qi" (理氣, li-khi) within Lê's masterwork, the Yuntai leiyu (芸臺類語, Vân đài loại ngũ,, Classified Discourses from Yun Terrace), in order to explore Lê Quý Đôn's thought, especially those aspects that were influenced by Zhu Xi.

\section{Zhu Xi's Thought in Lê Quý Đôn's Yuntai Leìu (Vân đài loại ngũ̃)}

Within Lê's vast philosophical output, Yuntai leiyu (Vân đài loại ngũ) ranks as the most important. Many Chinese scholars believe that Lê Quý Đôn was strongly influenced by the philosophy of Zhu Xi (1130-1200), one of the preeminent Confucian scholars of the Southern Song dynasty, citing Yuntai leiyu (Vân đài loại $n g \tilde{u})$ in support of that opinion (He 2000, 357; Yu 2000, 186-93).

Yuntai leiyu (Vân đài loại ngũ) consists of nine volumes, and in the work's "Author's Preface", there appears the phrase "after the full moon of the first month of autumn, Quý Tỵ year, Cảnh Hưng era” (景興癸已孟秋既望), meaning that the book was finished in 1773. However, the composition of the book likely lasted many years. Lê's friends commented on the writing of the text as follows:

Lê Quế Đường of Diên Hà District has read every book, and there is nothing he has not investigated. If he discovers something he will write it down immediately; his writings thus totally fill his desk and cabinet. Among them, Yuntai leiyu (Vân đài loại ngũ)) is the most excellent. Yuntai leiyu (Vân đài loại ngũu) is divided into nine volumes, classified and detailed according to proper principles. Astronomy, geography, and human affairs are all included. Studies based on gewu 格物 (investigating things, cách vật), zhizhi 致知 (extending knowledge to the utmost, trí tri), chengyi 誠意 (being sincere in one's thoughts, thành ý), and zhengxin 正心 (rectifying one's heart, chinh tâm); efforts to xiushen 修身 (cultivate one's self, tu thân), qijia 齊家 (regulate the family, tề gia), zhiguo 治國 (order well the state, trị quốc) and ping tianxia 平天下 
(pacify the world, binh thien $h a$ ): there is nothing that cannot be found in this book. (Tran 2011, 1-2)

Lê himself described the writing process for Yuntai leiyu (Vân đài loại ngũ) in his "Preface":

I would usually read books of numerous genres, such as biographies and historical records, and then summarize them, sometimes making comments according to my own ideas, sometimes just jotting down the original texts; after a while, those notes gradually accumulated and became a book. I arranged the contents in nine volumes and gave it the title leiyu (Classified discourses). (Lê 2011, "Preface", 5)

Based on the "Preface", it can be surmised that the so-called "tai" 臺 (terrace or stage, đài) in Yuntai (芸臺, Vân đài) is a reference to a lantai (蘭臺, Lan đài), or "orchid terrace": that is to say, a room containing many books. ${ }^{5}$ It is evident both how many volumes Lê collected, and that the Yuntai leiyu (Vân đài loại ngũ) was the result of this research process. Using a large number of anecdotes, quoting liberally from the Classics while adding his own comments, the text of Yuntai leiyu (Vân đài loại ngũ) resembles an encyclopaedia, with its division into categories, or lei; looking more closely, one can see that the book is divided among nine subject areas, which correspond to the nine volumes of the book: $L i-q i$ (理氣, Principle and Material Force), Xiangxing (象形, Image-Form), Quyu (區宇, Area-Universe), Dianhui (典彙, Standard-Class), Wenyi (文藝, Literature and Art), Yinzi (音字, Sound and Character), Shuji (書籍, Written Works), Shigui (仕規, Official Regulations), and Pinwu (品物, Objects). These nine volumes cover many subjects, but can be organized into three general groups: "writings on Heaven", or tianwen (天文, Thiên văn); geography or “Earthly principles", dili (地理, Địa li); and "writings on human matters", or renwen (人文, Nhân văn). The organization of the book reflects both Lê's convictions and his broader intellectual orientation.

4 I had the opportunity to read two manuscripts of Yuntai leiyu (Vân đài loại ngũ). The first was photocopied from an edition in the possession of the Institute of Philosophy of Vietnam Academy of Social Sciences, which consists of three parts and volumes. The second was photocopied by National Taiwan University and based on a manuscript in the possession of the Library of the Hán-Nôm Research Institute, Vietnam. There are some differences between those two scripts. The citations in this paper are mainly based on the latter manuscript published by National Taiwan University.

5 Yunxiang 芸香 refers to the common rue, a fragrant grass, while the yuntai, also known as a lantai 蘭臺, refers to a room containing secret books in the Han dynasty. This word also refers to officials responsible for collecting and managing the books therein. According to Yu Xiangdong, "the socalled yun refers to the 'common rue'. Yuntai means a place for the storage of books" (Yu 2000, 182). This opinion deserves further discussion. 
It can be observed from Lê's "Preface" that he composed the book according to Zhu Xi's concepts of gewu and zhizhi. Lê explained this influence, noting:

The ancients said that the investigation of things and extension of knowledge to the utmost, if brought to the effect of "cultivating the person", "regulating the family", "ordering well the state", and "pacifying the world", can be said at that point to be extremely broad. The Dao exists in all things; everything has the Dao. From Heaven and Earth right down to human relations and daily matters, everything has its own principle, has its own meaning. The junzi thus cannot remain ignorant of it. Through learning to gain knowledge, asking questions to make distinctions, studying the old and knowing the new, being honest and sincere in one's reverence for ritual, and accumulating knowledge by day and night, one will naturally link the threads (guantong 貫通). Studying principles deeply and fulfilling one's nature (窮理盡性) in order to arrive at one's fate; extracting the essence of the meaning and being enthralled in order to apply it; there is nothing that does not originate from this (learning). (Lê 2011, "Preface", 3)

From the outset, Lê regarded Zhu Xi's theory of gewu zhizhi as the basis for his book's composition. For Zhu Xi, gewu zhizhi was the central element of his theory of cultivation (工夫論). With self-cultivation, one can fully explore the relationship between Heaven and man (jiu tianren zhiji 究天人之際), and obtain the effect outlined in the Great Learning of xiu-qi-zhi-ping 修齊治平 (self-cultivation, regulating the family, ordering the state, and pacifying the world). The foundation for this practice of cultivation lies in Zhu Xi's li-qi theory. According to $\mathrm{Zhu} \mathrm{Xi}$, "things in the world must have the causes why they are so, and the standards for what they ought to be; these are called $l i$ (principles)" (Zhu 2001, 8). Zhu Xi's ontology begins with the concept of $l i$, in which $l i$ is the encompassing principle of the universe and things in the world, the basis for all existence. Hence all things in the world have both "the reasons why they are so" and "the standards by which they ought to be so"; the principle of existence and the principle of what ought to be cannot be separated. Efforts to "investigate things" and "extend knowledge to the utmost" thus, for Zhu Xi, are identical to the process of studying the principle of the existence of all things, as well as the principles of what ought to be. That concept had a major influence on Lê, and became the basic position expressed in Yuntai leiyu (Vân đài loại ngũu). Lê's statement that "the Dao exists in all things; everything has Dao" means that "there is nothing (in the world) that has no principle; there is nothing that has no meaning". In other words, everything in the world is "being" (有), not "nothing" (無). Affirming the existence of that 
being, the junzi has a duty to manifest the value of things' existence. According to this interpretation, gewu zhizhi has a positive function and becomes the necessary direction that one must pursue.

Lê's interpretation of the theory of gewu zhizhi, similar to that of Zhu Xi, prioritized the acquisition of external knowledge, emphasizing wide-ranging study (boxue) and curiosity. Lê wrote:

The I Ching said: "The junzi remembers the words and deeds of former men, to serve the accumulation of his virtue". The Book of Documents said: "The junzi should seek to learn much, with a view to establish his affairs". The Analects said: "Why do you not study the Book of Poetry? From it you can learn how to serve your fathers, and to serve your rulers, and be well-acquainted with the names of birds, beasts, and plants". ${ }^{6}$ All of these are efforts to investigate things. If we can keep the principle and choose the quintessence, then, although things ancient and contemporary may be confused in front of our eyes, we will be able to consider the whole process from beginning to end, to integrate the start with the finish, and gradually recognize that things have different paths but return to the same place, that hundreds of concerns have the same final intention. If this is so, then who can criticize us by claiming that [our understanding is] wide-ranging but has no finesse, that we are diligent without effect? (Lê 2011, "Preface", 3-4)

According to Lê, persistent listening and understanding entail a zhizhi effort, and possess positive functions. With such efforts, we can face confused things and come to the right decisions, distinguish where things begin and end, and arrive at the simple from the complex. It is clear from this that, when it came to gewu zhizhi efforts, Lê emphasized the positive meanings acquired by an expansive approach to knowledge accumulation, and did not prioritize the moral practice that was closely integrated with gewu zhizhi in Zhu Xi's original thought.

Although Yuntai leiyu (Vân đài loại ngũ)) consists of many different sections concerning the study of Heaven, the study of Earth, and human matters, the effort to achieve gewu zhizhi remains constant throughout. Lê wrote:

The sun, the moon, and the stars are phenomena of Heaven (tianwen 天文, Thien văn). Though the climate may different here and abroad, take the points in the sky where stars stop, the locations where stars

$6 \quad$ Translated into English by James Legge (I Ching, Da Xu, 1; Shang shu, Charge to Yue III, 8; Lunyu, Yang Huo, 9). 
moves: how can any of them not have a constant (principle)? Mountains and rivers, plants and grass are phenomena of the Earth (diwen 地文, Đị văn). Between them their forms are different, but take the entirety of their vascular systems, whether they be tall or short, fat and thin: how can any of them not have a constant principle? Rites, music, systems of law are all human phenomena (renshi 人事, nhân sư'). The transformations of past and present, the values and pleasures of people inland and abroad are different from one another, but the means by which teaching is established according to the times, by which one understands historical changes in order to suit the people's needs, is unitary. (...) The jun$z i$ of ancient times practiced it, the junzi of current ages follow it; the so-called "investigation of things" is this; the so-called "extension of knowledge to the utmost" is this; the so-called "grasping of all principles to respond to all matters" is also like this. This does not mean hovering about, following only the outside appearance and not considering the interior of things. If we do not make like this, and instead investigate things bit by bit, then it will be just like the proverb in which one "loses the goat amidst the many side-roads". (Lê 2011, "Preface", 4-5)

In Lê's view, the affairs of Heaven, Earth, and man are always in continuous flux, but they have a point of connection: the constant, unchanging $l i$ (principle, li). Through the effort to gewu zhizhi that Zhu Xi proposed, we can grasp that flux, and at the same time understand the constant $l i$ possessed by all things in the world.

For this reason, various aspects of Yuntai leiyu (Vân đài loại ngũ), from the material collected, to its different categories, to its compilation of concepts and ideas, draw on Zhu Xi's theory of gewu zhizhi. The tendency towards diversity in the kinds of knowledge included is apparent in Yuntai leiyu (Vân đài loại ngũ). As Lê wrote:

I think, if things I mention are too sophisticated, they will be lofty and empty, and if they are the opposite, they will be too superficial. However, if they cover all aspects of things in broad strokes, then they will be useful for studying the three powers (sancai 三才, tam tài) (Heaven, Earth and man) and dealing with all manner of things. (ibid., 6)

Thus the refined abstractions of xin (mind, tâm), xing (nature, tính), li (principle, $l i$ ), and $q i$ (material force, $k h i$ ), though they are of universal interest to Song-Ming Neo-Confucians, do not constitute the central elements of what Lê aimed to discuss in Yuntai leiyu (Vân đài loại ngũ). 


\section{Lê Quý Đôn's Theory of Li-qi}

The first volume of Yuntai leiyu (Vân đài loại ngũ), titled "Li-qi", is representative of Lê Quý Đôn's worldview and metaphysical thinking. Based on what Lê wrote in the "Table of Contents" (目錄引), we can understand his intention in compiling the volume:

Liangyi 兩儀 (Two polarities) fix the position, Erqi 二氣 (that is, Yin and Yang) push and rub up against each other; being human and being a thing means possessing a nature and a fate. $Y i$ 醫 (medicine), bo 卜 (divination), and fengshui 風水 (geomancy) are where the utmost $l i$ 至理 exists; Xian 偠 (Daoist super-being), Shi 釋 (Buddha), and guishen 鬼神 (ghosts and spirits) are all infinite and cannot be estimated. Standing in the middle of it all, it is necessary to follow only the constancy. Therefore I wrote “Li-qi yu” 理氣語 (Discourses on li-qi) as my first volume. (Lê 2011, 7)

For Lê, Heaven, Earth, and all things are formed thanks to the movement of "two $q i$ ", Yin and Yang, and have the supreme $l i$ existing within them. This means that within the moving $q i$ there must be an unchanging, constant $l i$ ruling and controlling (主宰). Not restricting himself to Confucian discussions, Lê also displayed an openness to diverse disciplines and modes of thought, including not only medicine, divination, and fengshui, but also Daoism, Buddhism, and theories of guishen, explaining them all through the $l i$-qi theory. Therefore, in the " $L i$-qi" volume, the 54 parts which concern $l i$ and $q i$ also discuss many other topics. Because Lê's theory of $l i$-qi is highly complex, I will not attempt a panoramic account but will instead perform a close analysis of typical paragraphs.

\section{What Fills Out Heaven and Earth is Qi; Li Exists Within Qi}

Lê's theory of li-qi in Yuntai leiyu (Vân đài loại ngũ) contains little metaphysics, even as it advances a large number of arguments concerning cosmology. I argue that Lê's heightened attention to qi-transformative cosmology (氣化宇宙論), coupled with his observations of Heaven, Earth and the "ten-thousand things" (wanwu), took the tradition of $q i$-transformative cosmology that originated in the Han dynasty as its basis and supplemented it with Zhu Xi's theory of li-qi. Lê wrote:

What fills out all between Heaven and Earth is qi. $L i$ means the real being, not nothing. $L i$ does not have figure or leave a trace, and can only 
be seen thanks to qi. Li exists within qi. Yin-yang 陰陽, ji-ou 奇偶 (the odd and the even), zhi-xing 知行 (knowledge and activity), ti-yong 體用 (substance and function): they can be mentioned separately, but $l i$ and $q i$ cannot. (Lê 2011, vol.1, 13-14)

This typifies the influence of Zhu Xi's thought on Lê Quý Đôn's theory of li-qi. We can see in the paragraph the phrase "what fills out all between Heaven and Earth is qi", which appeared so often in the Ming-Qing competitive-examinations that it became a cliché in the eight-legged essays (八股文, Bát cổ văn), and was used by numerous thinkers in the Ming-Qing dynasties. But the important thing here is the deeper implicit meaning of the statement. In Lê's opinion, Heaven and Earth - the universe - is full with the changes of transformative qi, which are the very traces left by creation.

However, that transformative $q i$ which is operating is not some abstract or unreal existence, but possesses a very real being. Thus Lê's concept can be regarded as a revision of Zhu Xi's theory of li-qi. In Zhu Xi's theory of $l i$-qi, the connection between $l i$ and $q i$ can be seen from two aspects. From an ontological perspective, $l i$ is the foundation of $q i$ 's existence; as Zhu Xi said, "after there is this $l i$, this $q i$ is produced" (Zhu 1986, 2). Li has the place of precedence here. With respect to cosmology, Zhu Xi writes: "without $q i$, there will be no place for $l i$ to rely on" (ibid., 3); qi possesses the ability to realize $l i$. Therefore Lê's statement that " $l i$ does not have figure or trace", continuing to say that "li can only be seen thanks to $q i$, and exists within $q i$ ", is typical of Zhu Xi's thought. Lê's claim that " $l i$ does not have figure or trace" means the metaphysical $l i$ cannot be seen, and that the physical (non-abstract) qi must be used in order to substantiate $l i$. When Lê stated that " $l i$ means being, not nothing", and " $l i$-qi cannot be mentioned in apposition", it is obvious that he accepted Zhu Xi's line of thought, according to which $l i$ is the real being, $l i$ and $q i$ are two essential concepts for the study of the universe, and they are not similar to Yin and Yang, or $t i$ and yong (substance and function), which can exchange between each other. The comment that "li and qi cannot be mentioned symmetrically" shows that $l i$ and $q i$ cannot exchange between themselves, and that $l i$ cannot be transformed into an attribute of $q i$. In this sense, the statement that "what fills out Heaven and Earth is qi" cannot be an argument for $q i$-monism (唯氣論), but instead emphasizes the inseparable connection between $l i$ and $q i$ that is shown in the phrase "li exists within $q i$ ", much as $\mathrm{Zhu} \mathrm{Xi}$, discussing the formation of the universe, stated that "in the world there is no qi without $l i$, and there is no $l i$ without $q i$ " (ibid., 2). That very concrete form in the world is an expression of the " $l i$ which exists within $q i$ ": this is one aspect of Zhu Xi's original theory of $l i-q i$. Thus, receiving Zhu Xi's theory of $l i$-qi, with his passionate 
interest in the $q i$ - transformative cosmology, Lê emphasized the positions that " $l i$ and $q i$ have a close connection and cannot be separated" (理氣相即不離), and that “li exists within $q i$ " (理在氣中).

The notion that " $l i$ exists within $q i$ " can also be expressed in another way: "li resides within $q i$ ” (理寓於氣). This was another of Lê's takeaways from Zhu Xi's theory of $l i-q i$ :

The I Ching says: "The benevolent see it and call it benevolence, the wise see it and call it wisdom. The common people, acting daily according to it, yet have no knowledge of it."7 The Yinfu jing (陰符經) says: "Its resource and device are one; it is invisible and unknown to all under the sky. When the superior man has got them, he strengthens his body by them; when the small man has got them, he makes light of his life." 8 The statements have the same meaning; the profundity of $l i$ and $q i$ is fully expressed here. The mysterious function of opening and closing, the mystical power of encouragement: they are granted to sages by Heaven, and are used by the sages to follow Heaven's way, to produce the myriad things, to complete the myriad changes, to stabilize the world's people and to bring in line all nations. (Lê 2011, vol.1, 32)

\section{Lê continued:}

The Dao mentioned in the I Ching always changes and is never at a standstill; it flows through all six voids (the sky, the earth and four directions), unceasingly going up and down. Thus it can comprehend the mysteries of $l i$ and $s h u$ 數 (number, divination; fate). $L i$ resides within $q i, s h u$ is due to $l i$. Being born to the mind (心), taking effect upon matters; that is the evidence of qi. Being calm and then thinking, thinking and then receiving, that is the accomplishment of qi. Receiving things to understand their sources, searching for the passing things to understand their ends, only the I Ching can do that. (...) Therefore the important thing for the comprehension of the I Ching is the ability to understand whether the Dao full or empty, increased or decreased, good, bad, or regretful, coming or passing; but the essential thing resides in not losing its rectitude. (ibid., 33-34)

$7 \quad$ Translated into English by James Legge (I Ching, "Xi ci I," 5).

8 Translated into English by James Legge (Yinfu jing, 7). The original text of the Yinfu jing is as follows: "the spring by which the despoilers are moved is invisible and unknown ..." (其盜機也、 天下莫能見、莫能知...). Lê Quý Đôn’s quotation is somewhat different. 
In the two quotations shown above, it is clear that Lê started from the premise that "li resides within $q i$ " in order to express the variety of changes undergone by the universe and all things. But he also emphasized the way to grasp the constant $l i$ within the unceasing changes of $q i$, the true sense of "the profundity of $l i$ and $q i$ " (理氣之奧). In other words, the sages foster all things; the Dao of the I Ching is the observation of constancy within change, the understanding of $l i$ within $q i$; this is the straightforward and simple Dao (yijian zhi Dao 易簡之道).

\section{The Formation and Generation of Heaven and Earth}

Lê Quý Đôn paid much attention to cosmology, and in the volume " $L i$-qi" there are many arguments concerning $q i$. Here I will focus only on those statements mentioning Heaven and Earth that are directly connected to qi. Lê explained the formation of Heaven and Earth as follows:

How great is the originating power of Qian (乾)! All things rely on it to begin; that it is to say, its $q i$. How supreme is the originating power of Kun (坤)! All things rely on it to be born; that is to say, its xing 形 (form; shape). To speak with respect to Heaven and Earth, each possesses form (xing) and qi; to speak with respect to the myriad things, they receive energy from Heaven, and take form thanks to the Earth. (Lê 2011, vol.1, 13)

In Lê's thought, "Heaven and Earth" refer to the basic principles of the creation of the universe, and Qian and Kun refer to the natural world. The sign Qian governs the virtue of Heaven, signifying the principle of creation, providing the basis for the beginning of the myriad things; Kun governs the virtue of Earth, signifying the principle of actualization, providing the basis for the birth of all things. But Lê explicates the virtues of Qian and Kun through the qi-transformations of Yin and Yang. Thus the creation of the myriad things is the mixture of the qi of taiji with the principle existing within qi. Analytically speaking, it is the $q i$ of Yin and Yang that is used to explicate the composition of the universe and all within it.

All those arguments are meant to explain the formation of Heaven and Earth. Accordingly, Heaven belongs to yang qi, the Earth belongs to yin qi, or, in other words, Heaven belongs to pure $q i$ and the Earth to turbid $q i$. Thus, from the aspect of Qian's originating power, which refers to Heaven, qi denotes the invisible $q i$; from the aspect of Kun's originating power, which refers to the Earth, xing denotes the visible $q i$. In the movement and interchange between Yin and Yang, Heaven is $q i$ and the Earth is xing, and thanks to this Heaven and Earth are produced. The following statement explains the production of things: "Things receive $q i$ 
from Heaven and take form thanks to Earth". According to this view, Heaven and Earth are both encompassed by the transformations of Yin and Yang. This is the model of traditional $q i$-transformative cosmology. Zhu Xi made a similar argument, writing: "By means of qi, Heaven clings to the xing of the Earth; by means of xing, the Earth clings to qi of Heaven" (Zhu 1986, 6). He continued: "At the beginning of Heaven and Earth, there are but Yin and Yang", and that "the light and pure thing is Heaven, the heavy and turbid thing is the Earth" (ibid.). The Qi and xing that Lê Quý Đôn mentioned in "the Heaven and Earth" are identical to the $q i$ and $z h i$ 質 (matter) that $\mathrm{Zhu} \mathrm{Xi}$ and other Song-Ming theorists of $l i$ mentioned. $Q i$ means the invisible $q i$; the invisible $q i$ gathers and thus accomplishes zhi (i.e., form, or xing); consequently Heaven and Earth are constituted by xing (or $z h i$ ) and $q i$.

What of the formation of Heaven and Earth? Lê explained this based on the concept of ti-yong (substance and function):

Viewed from the perspective of distribution, Heaven belongs to Yang, Earth to Yin; Yang maintains activity (主動), and Yin maintains motionlessness (zhujing 主靜). However, the function (yong) of Heaven is in perpetual motion, though its substance $(t i)$ is motionlessness to some extent; the substance of Earth is perpetually motionless, but its function moves to some extent. If Heaven were not motionless, then how would the Four Directions (四維) be secure and stable? What would the Seven Celestial Bodies (七政) have to rely on? If the Earth were not moving, it would just be a mere thing, with almost no vital energy. Heaven's form is active and its $q i$ is motionless; the Earth's form is motionless and its $q i$ is active. (Lê 2011, vol.1, 14-15)

Maintaining that Heaven and Earth are constituted by means of xing and qi, Lê extended his discussion to analyse more deeply the Yin and Yang that form xing and $q i$ 's construction, as well as their interactive functions, which make the universe's myriad things multiply unceasingly. Lê relied on Zhu Xi's view of $t i$ yong, pointing out that, although Heaven acts and develops due to yang qi, its essence is never not motionless, but is instead the most motionless substance, thereby allowing Heaven's four corners and the Sun, Moon, and five planets to be stable. Similarly, although the Earth belongs to yin qi, it is not an immovable thing. Its essence is motionless, but its function is accomplished by interactions between Yin and Yang. In brief, Lê maintained the position that "Heaven is motionless and the Earth is moving". In other words, if we consider Heaven and Earth in general, we can divide them by Yin and Yang, motionlessness and movement, substance and function; but when considering the formation of Heaven and 
Earth, we see that there is always interaction between Yin and Yang, substance and function, motionlessness and activity: that everything is in a state of unceasing growth and development.

\section{Changes of Fengqi}

Lê Quý Đôn explained the formation and transformation of Heaven and Earth through a discussion of interactions between Yin and Yang. Natural phenomena could be observed readily in Lingnan area in southern China, allowing Lê to make observations of the various manifestations of Heavenly $q i$ in nature, among them the changes of fengqi 風氣 (atmosphere; wind and air). Lê commented:

All below Heaven and above the Earth is fengqi. Near places where people live, one does not perceive there being wind, likely because there are many obstacles and life forces (shengyi 生意) that combine to make it disappear. In high places, the wind becomes strong; the higher the place is, the stronger and harder the wind becomes. In addition, if we dig a hole of about 2 meters at the foot of a mountain, we can see that the soil brought up is at first soft and wet, and afterwards becomes solid as a rock. Is this not because of contact with the wind? When still being a foetus, an infant is nothing but a clot of blood; after being born it becomes solid, due to the same reason. The Heaven's qi comes down, the Earth's $q i$ rises up, those $q i$ are all vital forces. There is no time in which the fengqi circulating in that space does not exist; it is not that it exists when moving and does not when motionless. (ibid., 17)

In Lê's view, there is always circulation and change of $q i$ in the space between Heaven and Earth; when it comes to the invisible qi, the most concrete aspect of which and that which can be felt directly is the wind (風, phong), which he called fengqi (風氣, phong khi). Through the observation of natural phenomena, he saw that the wind is strong in high places because there are no obstacles, and that at extreme heights there is nothing but the wind. By the same logic, he conjectured that the soil when underground is soft and wet, and when put on the ground becomes solid because of the wind; and the condition of infants in the womb and after birth is also related to changes in the wind. Thus, in Lê's view, the descent of Heaven's $q i$ and the ascent of Earth's qi naturally form the exchange of Yin and Yang, and is called fengqi. The movement of fengqi is the vital energy of Heaven and Earth, whether motionless or in motion, fengqi is always moving unceasingly. It can be seen from natural phenomena that the "invisible qi" is atmosphere or 
the air, and the wind that is comprised of and begins to move from qi can penetrate all objects and spaces; thus Zhu Xi also stated, based on his observation of nature, that "wind is a thing that can enter every other thing" (Zhu 1986, vol. 39, 2287). However, Lê Quý Đôn wanted to use the wind as a natural phenomenon to understand other natural phenomena, signifying his high level of interest in natural cosmology. From the standpoint of modern natural science, it can be said that although Lê's explanations are simplistic, they demonstrate that his qi-transformative cosmology was based on the observation of nature.

Lê's attention to fengqi can also be seen in his writing on jufeng 颶風 (typhoon, hurricane):

In the word $j u$ 颶 (typhoon, hurricane), there is the word $j u$ 具 (to possess all). That means it consists of all the winds: East, West, South and North. If the typhoon starts to blow in the morning, it will last for three days; if it begins in the afternoon, it will last for seven days. The typhoon starting at noon will last only one day. When the typhoon starts to blow, if it blows in from the northeast, then it will blow from North to West. If it blows in from the northwest, then it will blow from the North to the East. All turn South and cease. This is called "falling onto the West" and "returning to the South". If they do not fall onto the West or return to the South, then there will be another typhoon one month later. The typhoon is always on time: if it starts in the daytime, it will end the following day after, if it starts in night-time, it will drop the following night. Jufeng is an improper wind, with changes that go contrary to qi, but it still has a constant principle like that. (Lê 2011, 18-19)

Lê's explanation of jufeng shows that he paid much attention to changes in feng$q i$. For Lê, a jufeng was not a "proper wind", but rules of movement can still be discerned in it. Such an explanation cannot be experimentally verified by modern science, but it is representative of a pre-modern Chinese view of nature which relied on $q i$ - transformative cosmology, and also displays Lê's broad vast knowledge in the field of gewu (investigating thing).

Besides his explanation of natural phenomena based on fengqi, ${ }^{9}$ Lê Quý Đôn also had a positive attitude towards the theory of fengshui 風水, ${ }^{10}$ writing:

9 As Lê wrote: "Dry $q i$ is wind, if the wind scatters then it will be clear; the wet $q i$ are clouds, if the clouds gather then it will rain. All of them are the harmonious and fluent $q i$. The dry $q i$ and the wet $q i$ combine and produce fog; heavy fog produces miasma; that is the foul and constricted qi." (Lê 2011, 18)

On the theory of fengshui, see Needham 1984, 23-30. 
Hengqu 横渠 (Zhang Dai) did not believe in fengshui, but he said: "People in the south trust in the Qingnang jing 青囊經, so it must be reliable". The southerners test the place to bury the dead by putting a silk thread of five colours underground. After a few years, they take it up and examine it. If the colour of the thread does not change, then the soil is good; if the colour fades, then the soil is not good. They also put a small fish into a jar full of water and bury it for a few years. If the fish is still alive, then the soil there is good, if it is dead, then the soil is bad. Thus, we can use the health of plants to understand whether the soil there is good or not. (Lê 2011, vol. 1, 36)

The qi-transformative cosmology had been a traditional mode of thinking among the Chinese people ever since the Han, but Song-Ming Confucians pioneered a new concept, in which ethical-rational thinking was seen as the foundation for the study of the world and all it contains. Thus Zhang Dai 張戴 (1020-1077), the Song dynasty Neo-Confucian who discussed $q i$ the most, did not believe in fengshui theory at all. However, Lê cited Zhang Hengqu's observation of natural phenomena, suggesting that fengshui theory does agree with $q i$-transformative cosmology, and that theories of medicine, divination, and fengshui, which consider phenomena based on changes in fengqi, have their own principles that should not be disregarded.

\section{Tianren Hede and Tianren Ganying}

Lê not only paid attention to $q$ i-transformative cosmology but also accepted the Neo-Confucian concept of Tianren hede 天人合德 (harmony in virtue of man with Heaven, Thiên nhân hơp đức), as well as the idea of Tianren ganying 天人 感應 (mutual interaction of the Heaven and man, Thiên nhân cảm ứng) that had taken deep root in China from the Han dynasty onward. In the chapter " $L i$-qi", the opening statement reads as follows:

Heaven regards $x u$ 虛 (emptiness) as the Dao, the Earth regards jing 靜 (motionlessness; calmness) as the Dao; if man is empty and motionless, he can unite with the Dao of Heaven and Earth. Because if he is empty then he will clarify himself (ziming 自明); if he is motionless, then he will be settled by himself (ziding 自定). A clarified mind and a settled principle; these are the very effects of participation and assistance. (ibid., vol. 1,13$)$ 
Here Lê did not use Yin and Yang to describe the Dao of Heaven and Earth, but relied on $x u$ and jing to explain their virtue. Thus man, united in virtue as Heaven and Earth, should use $x u$ and jing to become harmonious with the Dao of Heaven and Earth, and those who possess clear minds and settled principles can participate and assist in the cultivation of Heaven and Earth. In actuality, the virtue of $x u$ and jing and the clear mind and settled principle Lê mentioned are the same “motionless mind and clear principle" (心靜理明) that Zhu Xi emphasized, and are in agreement with his theory of gewu zhizhi.

The most important thing that allows Heaven and man to share the same virtue is the rectification of man's mind (zhengxin 正心). Therefore, Lê Quý Đôn wrote:

The mind of man is extremely great; it can communicate well with Heaven and Earth, measure guishen 鬼神 (ghosts and spirits), and investigate all things. The mystery of xiang 象 (appearance) and shu 數 (fate, number), scattering over xing 形 (form) and qi, going out from $w u$ 無 (non-being) to you 有 (being), entering to $w u$ from you: within both obscure and clear space, everything is the Dao. If man has a right mind, he can understand the Dao; if he understands the Dao, he can see $j i$ 幾 (a tiny thing; an opportunity); if he sees $j i$, he can fulfil his function; if he fulfils his function, he can attain power. Fate is produced by man; it cannot produce man. The principle of Tianren heyi 天人合一 (the oneness of Heaven and man, Thiên nhân hợp nhất) is no more than that. (ibid., vol. 1, 31-32)

Lê clearly emphasized the positive, active nature of the rectification of man's mind; only with a right mind can man understand the Dao and apply the principles of Tianren hede and Tianren heyi. The rightness that Lê emphasized here typifies the thought of Neo-Confucianism, especially Zhu Xi's concept of Tianren hede.

In spite of this, based on his great interest in qi-transformative cosmology, Lê was nonetheless influenced by the Han dynasty theory of Tianren ganying (mutual interaction between Heaven and man, Thiên nhân cảm ứng). Using a solar eclipse as an example, he argued as follows:

Solar eclipses have constant laws of behaviour, but they usually have a connection with changes in human matters. When a man is about to do evil, at that moment the moon enters the eclipse phase, and approaches to covers the sun; it is the qi of man that affects Heaven. When Heaven wishes to produce clouds or rain, then a man who was beaten or injured feels a sharp pain; this is how the qi of Heaven affects man. Thus Heaven and man share the same $l i$. (ibid., vol. 1, 24) 
He also considered the interactions between the change of the natural qi and the vicissitudes of life:

The actions of $q i$, how mysterious and refined they are! If $q i$ is abundant then it will be comfortable; if it is decreased then it will be reduced. This can be seen through the growth and withering of plants. If $q i$ is pure then it will be flowing; if it is turbid then it will be obstructed. This can be seen in the brightness and darkness of the human mind. If $q i$ is full then it will grow; if it is empty it will disappear. This can be seen in the morning and afternoon tides. If $q i$ is harmonious it will be united; if it is irregular it will be separated. This can be seen in the vicissitudes of life (世道之 治亂). (ibid., vol. 1, 23-24)

Comparing the changes brought on by eclipses to changes in human matters is typical of the Han Tianren ganying concept; and the concept of a principle shared by man and Heaven that is obtained from the empirical observation of natural phenomena, in which man's qi affects Heaven and Heaven's qi affects man, is an explanation based on a transformative $q i$, not on a vision of the shared virtue of Heaven and man. Similarly, the unceasing changes of $q i$, the interactions between Ying and Yang, purity and turbidity, between brightness and darkness of human mind, between changes of nature and the vicissitudes of life: their relations of inevitability are effected based on the mutual interactions of transforming $q i$, not on the self-consciousness of morality. All of the preceding arguments show connections with the Tianren ganying concept and its intellectual connection with $q i$-transformative cosmology.

\section{Guishen, Daoism, and Buddhism}

The Song-Ming theory of Tianren hede (harmony in virtue of Heaven and man) and the Han concept of Tianren ganying are both reflected in Lê Quý Đôn's explanation of guishen 鬼神 (ghosts and spirits, quy thần). In the 54 discourses on li-qi contained in Lê's book, one quotes Zhu Xi's theory and then comments as follows:

Zhuzi said: "Bending and extending, going and coming, that is $q i$. The $q i$ of man and that of Heaven and Earth connect with one another without interruption. The human mind moves slightly and immediately reaches $q i$, and interacts with that $q i$ which bends and extends, goes and comes. Like in divination, all within the mind inherently has this thing, and it 
only takes something to come up within the wind; as soon as it moves, it immediately interacts." He also said: "Man receives the qi of the wuxing (五行, five elements); that qi must pass through the human body. Current people use the wuxing to infer man's fate, much as the geomancer seeks and selects whether something should face or turn its back to the mountain or the forest; all of these things share the same li." I would say: it can be seen in those two statements that Zhuzi not only appreciated divination, but also that he did not neglect discussions on fate (命數) and appearances (形象). People who are fond of disputation usually exclude those two theories, but in the last analysis they have a connection with $l i$ and $q i$ and so cannot be disregarded. (Lê 2011, vol. 1, 34-35)

For Song dynasty Neo-Confucians of $l i$ such as Zhang Zai or Zhu Xi, guishen are nothing but $q i$, bending and extending, going and coming. Thus Zhu Xi said: "guishen are but qi", "nothing but yin and yang, decreasing and increasing"; adding that "shen means extending, gui means bending; wind and rain, thunder and lightning: the moment when they start is shen, the moment when they stop and pass is gui" (Zhu 1986, vol. 3, 34). It can be seen that in Zhu Xi's discourse on guishen, there is no sense of mystery at all. When it came to the mysterious theories of guishen circulating among the common people, Zhu Xi regarded them with the traditional negative attitude attributed to Confucius: "While you are not able to serve men, how can you serve guishen?" Thus, Zhu Xi said, "Serving guishen must be the second thing. Those without form or shadow are very difficult to understand, thus one should not spend time to understand them, but instead devote one's efforts to daily urgent matters" (ibid., 33). When it came to divination, Zhu $\mathrm{Xi}$ also based his position on the idea that "if the mind is sincere, then one may interact with the spirits". Similarly, much like inferences about human fate drawn from the five elements and the geomancer's inferential selection of fengshui, when it comes to inferences about $q i$, if one has $l i$, then they can be followed. In the discourses of $\mathrm{Zhu} \mathrm{Xi}$ above, it is crucial to note that he mentioned divination and theories of fate and physiognomy to clarify the interactions of $q i$, but Lê quoted them to emphasize that Zhu Xi had an appreciation for divination and fengshui. Consequently, in his theory of $l i$-qi, Lê had a positive attitude toward the mysterious explanation of guishen which was circulating among the common people, as well as their understandings of divination, fate, and fengshui, among others. ${ }^{11}$

11 Lê even cited historical figures as examples to justify divination. He wrote: "Chengzi said: 'The ancients used divination to remove doubts, but later generations did not. They practice divination only to understand their fates and whether they will be successful or not.' I think sages established their instruction so that people can decide and deal with their doubts, not to teach people to seek profit and success. Thus it is said that 'the I Ching is not for small men to seek profit.' But when 
Similarly, Lê was tolerant toward Daoism and Buddhism, writing:

Daoist theories focus on refining the form, Buddhist theories focus on refining the spirit. Form and spirit are all produced from $q i$; when $q i$ gathers, the Dao is completed; when $q i$ scatters, the Dao is incomplete. Taking the sun and moon as examples: Daoism is like their substance, Buddhism is like their shadow. The substance is in the heavens on high, but it cannot be said to not be there, while the shadow dissipates in the water, but it cannot be said that it does not exist. (ibid., 47)

For Lê, Daoism emphasized the refinement of form, while Buddhism emphasized the refinement of spirit; form and spirit, when it comes to $q i$, can be encapsulated by the Confucian statement about qi-transformative cosmology mentioned previously, namely that "things receive $q i$ from Heaven, and take form thanks to Earth". Even though most Confucian scholars would not have believed in the Buddhist theory of samsara (輪迴, luân hồi), Lê had a positive attitude toward it. ${ }^{12}$ Consequently, he did not use the theory of $l i$-qi to reject Daoism and Buddhism, unlike Song-Ming Confucian scholars; by contrast, he regarded the theory of $l i-q i$ as a common theoretical framework shared by all three teachings.

\section{Lê Quý Đôn's Reception of and Appreciation for Western Missionaries and their Natural Scientific Knowledge}

As a prominent Confucian scholar with substantial international perspective, Lê had a considerable interest in the Western theories of nature that had been introduced into China in the 17 th and 18 th centuries. Lê wrote:

the gentlemen encounter doubts in their self-management and thus want to consult guishen, for example: Bi Wan divining his official career, Zhong Er of Jin divining his return home; although they did for themselves, such deeds did not harm their orthodoxy." (Lê 2011, vol. 1, 51-52)

12 Lê wrote: "There is the theory of samsara in the Buddhist classics that Confucian scholars usually do not trust. But things that people have long since seen and heard and then recorded are uncountable, the majority of them cannot but have this li. Confucius said: 'The virtue of guishen is much abundant. We look for them, but do not see them, we listen to but do not hear them. They seem to be over the heads, and on the right and left of worshipers' (Zhongyong, ch.16). The theories of underworld seem to be fabulous. But, generally speaking, it is because of the mystery of creation and the separation between Yin and Yang that people are unable to see and hear. When worshiping, gui and shen come down to observe; this is the gathering of the spirit although the body has been turned to dust. The Buddhist classics discuss the process of 'receiving the form and being reincarnated'; this is the same as knowledge of shen. The quintessence of the sun and the moon comes down and becomes water and fire; the qi of water and fire rises up and becomes wind and thunder. The mystery of Heaven and Earth's changes cannot be measured, let alone the people." (ibid., 48-49) 
The book by the Westerner, Kunyu tushuo 坤輿圖說 (Illustrated Explanation of the Entire World, Khôn du đồ thuyết), said: "Without qi, the interior of Heaven is empty, how can the Earth be suspended by emptiness and reside therein?" It continues: "Birds fly because they are able to manage $q i$ (air) with their wings, just as man swims by managing the water with his arms." It continues: "Man waves hands toward the emptiness (the air), and then there emerges sound. If there is no $q i$, then there is nothing else that can produce sound. The emptiness is still and there is no wind in the air, but we can see the dust moving up and down in the light that gets between the cracks; it must be $q i$ that causes this." I have quoted these phrases to prove that qi really exists; it is odd that others are still surprised at it. The book Tonglun (On Penetration) by Xue Xuan 薛瑄 of the Ming dynasty writes: "When we wave a fan, we can see the wind blowing; it can be seen that there is nowhere without $q i$ between Heaven and Earth." It continues: "That dust unceasingly flies everywhere between Heaven and Earth, that is the result caused by qi."13 If we observe sunlight shining through a window, we can understand that this idea agrees with the statements above. The book Suwen 素問 (Simple Questions) also writes: "In coming up and down, going out and entering, $q i$ is never lacking.” (Lê 2011, vol. 1, 16)

\section{Lê went on to write:}

The ancients said: "From the Southern, Northern, Eastern, and Western seas there appeared sages whose minds and $l i$ are the same." (...) Limadou (Ricci), Nanhuairen (Verbiest), Airulüe (Aleni) and others from European countries of the West came to China during the Wanli reign of the Ming dynasty; their discussions of Heaven and Earth were extremely profound; their political principles and calendar had many things that previous Confucian scholars had not discovered. Although their language and writing were not similar, in terms of the minds and wills they possessed and the talent and intellect expressed by their depth

13 Lê Quý Đôn referred to Xue Xuan's text as Tonglun (On Penetration) in both of the manuscripts I was able to look through, but I suspect that Lê might have misunderstood, and that the text in question was actually the book Daolun 道論 (On the Dao). There are some slight differences between the statements that Lê quoted and the contents of Xue Xuan's Daolun. Xue Xuan's Daolun writes: "When we wave a fan, we can see the wind blowing; it can be seen that there is nowhere without qi." It continues: "Between Heaven and Earth, dust flies everywhere, never stopping, never interrupting: that is the result caused by qi. We can understand this if we see sunlight shining through a window. When we wave a fan, we can see the wind blowing; it can be seen that, between Heaven and Earth, there is nowhere without qi." (Xue 1985, 7) 
of knowledge, in what sense are they different from Zhongzhou 中州 (China)?" (ibid., 46-47)

It can be observed from the previous two quotations that Lê Quý Đôn had at least some knowledge of the Western natural philosophy that had been introduced into China prior to the 18th century by Jesuit missionaries such as Matteo Ricci (1552-1610), Giulio Aleni (1582-1649), and Ferdinand Verbiest (1623-1688), and it is apparent that he had read Verbiest's Kunyu tushuo 坤舆圖說 (Illustrated Explanation of the Entire World). The interesting thing here is that Lê still relied on a traditional Chinese $q i$-transformative cosmology to explain or come to terms with Western scientific conceptions of nature, a cosmology within which $q i$ or fengqi still are taken for granted for any comparison with Western natural scientific knowledge, making use, as well, of the traditional notion of "transforming qi". From this starting point, he endorsed the idea of Western and Chinese sages possessing kindred minds and wills, and positively evaluated the scientific knowledge of nature that Western missionaries introduced to China, especially their contributions to the creation of calendars.

\section{Conclusion}

Even though many Southeast Asian countries, including Myanmar, Thailand, Laos, and Cambodia, were influenced by Chinese culture to various extents throughout their histories, it was in Vietnam where the influence of Confucianism ran deepest by far. After its introduction in the early period, Confucianism became an essential part of traditional Vietnamese culture. Taking Lê Quý Đôn's theory of $l i-q i$ as a representative case study, this essay has shown some of the characteristics of that indigenization of Confucianism. The Later Lê (1428-1789) saw Confucianism reach a zenith; Lê Quý Đôn, who lived at the dynasty's end, can be regarded as the great synthesizer of Vietnamese Confucianism. His output was prolific, consisting of discussions of Confucian classical texts and covering astronomy, geography, and social matters; it also reflected his international experience, gained from two diplomatic trips to Qing China. Among his works, Yuntai leiyu (Vân đài loại ngũ) typifies his encyclopaedic knowledge and reflects the depth of influence exerted by Confucianism on his thought. Consisting of nine volumes, the "Preface" of Yuntai leiyu (Vân đài loại ngũ) confirms that basis for the book's compilation stemmed from Zhu Xi's concept of gewu zhizhi and his position that Confucian scholars, in their efforts to investigate the $l i$ in all things, must fully study the constant $l i$ amidst a always changing world, relying on those efforts in order to cultivate their persons, regulate their families, order their states 
and pacify the world. The fact that Lê named the first volume of Yuntai leiyu (Vân đài loại ngũ) " $L i$-qi" gives further evidence for his attraction to and appreciation for Zhu Xi's li-qi theory.

However, from my analysis of the contents of that same volume, I have found that Lê Quý Đôn's concept of $l i$-qi draws on a traditional qi-transformative cosmology which originated in the Han dynasty, and at the same time was influenced by Zhu Xi's view that " $l i$ and $q i$ are not separate". Lê affirmed that "what fills out the Heaven and Earth is qi", showing a deep interest in cosmology. At the same time, he emphasized that " $l i$ exists within $q i$ ", referencing a search for a constant $l i$ within a transforming $q i$. The viewpoint that " $l i$ is not mixed with $q i$ " and the metaphysical arguments (such as the views that "it is $l i$ that produces $q i$ " or that " $l i$ comes first, $q i$ comes later") are thus not the main elements of Zhu Xi's theory of $l i$-qi to which Lê paid attention. Additionally, within Lê's theory of $l i$-qi, although Lê regarded the Neo-Confucian viewpoint of tianren hede as a central element, he still maintained the position of tianren ganying that was typical of Han $q i$-transformative cosmology. Therefore, Lê's thought is not identical with the Song-Ming Neo-Confucianism, with its reverence for rational nature as well as its rejection of "irrational" remnant elements of Han qi-transformative cosmology.

By contrast, Lê Quý Đôn combined Song-Ming Neo-Confucianism with Han $q i$-transformative cosmology to create his own theory of $l i$-qi, and was able to harmonize the three teachings of Confucianism, Buddhism, and Daoism, in so doing perpetuating an extant Vietnamese tradition of syncretism. He also had a positive attitude toward theories of medicine, divination, fengshui, and guishen, drawing on Vietnamese folk customs. In particular, based on his observations of the transforming $q i$ of Heaven and Earth, he emphasized the diversity of fengqi, and analysed the differences between foreign and domestic, as well as ancient and contemporary, conditions and customs. Finally, while still relying on the theory of $l i$-qi, Lê accepted the Western natural science that had been introduced to China in the 17th and 18th centuries, and maintained an open-minded and positive attitude towards the teachings of Jesuit missionaries.

But the metaphysical viewpoint is not the most important aspect of Lê Quý Đôn's theory of $l i$-qi. When examining the diversity of fengqi discussed in his thought, we can see the reciprocal influences of the natural environment, history, and culture of Vietnam, reflecting what the Japanese scholar Tetsuro Watsuji called specific “climatic features", or füdo 風土. For Watsuji, fūdo is generic term referring to the atmosphere, climate, geography, quality of the soil, and landscape of a given area, also called its “natural environment" (水土) (Watsuji 1962, 7). However, for Watsuji, climate is not only explained by natural features, but can also be seen as 
a humanistic concept, reflecting a reciprocal influence (ibid., 24-43). ${ }^{14}$ Similarly, what Lê Quý Đôn emphasized in his theory of $l i$-qi were the reciprocal influences among transformative qi, geography, fengshui, and fengqi, and their impact on customs, cultures, and habits. Likewise, if research on the development of Vietnamese Confucianism is based on a theory of "climactic features", it will reveal more of the richness of Vietnamese Confucianism than studies narrowly focused on metaphysics or doctrine of heart-mind and human nature, and will allow the characteristics of the localization of Vietnamese Confucianism to be shown more clearly.

\section{References}

Bui, Ton Am 裴存庵. n. d. "Queduong xiansheng chengfuli mensheng shedian jiwen 桂堂先生成服禮門生設奠祭文 (Quế Đường tiên sinh thành phục lễ môn sinh thiết điện tế văn, Text of the Disciple to Worship Master Que Duong at the Mourning Rites).” In Huangyue wenxuan 皇越文選 (Hoàng Việt văn tuyển, Hoang Viet Literature Collections), vol. 4. Vietnam.

Chen, Lai 陳來. 2008. Dongya ruxue jiulun 東亞儒學九論 (Nine Essays on East Asian Confucianism). Beijing: Sanlian shudian.

He, Chengxuan 何成軒. 2000. Ruxue nanchuanshi 儒學南傳史 (History of the Introduction of Confucianism into the South). Beijing: Peking University Press.

I Ching 周易 (The Book of Change). Translated by James Legge. Accessed September 30, 2019. https://ctext.org/book-of-changes.

Lê, Quý Đôn 黎貴惇. n. d. Beishi tonglu 北使通錄 (Bắc sứ thông luc, Records of Diplomatic Trip to the North).

_. n. d. Fubian zalu 撫邊雜錄 (Phu bien tạp luc, Notes on Ruling on the Border).

—. 2011. “Yuntai leiyu 芸臺類語 (Vân đài loại ngũu, Classified Discourses from Yun Terrace).” In Yuenan Ruxue yanjiu congshu 越南儒學研究叢書

14 According to Watsuji's typology of füdo, Vietnam can be seen as a typical monsoon area. Tetsuro Watsuji's theory of füdo emphasizes the inseparable connection between natural and humanistic features; in Watsuji's conception, Vietnam belongs to the monsoon area. This has encouraged me, in my studies of Vietnamese Confucianism, to pay attention to the role of climate, broadly conceived, and especially to the influence of climate on social factors, rather than focusing exclusively on metaphysical thinking. Thus Vietnamese Confucianism, in contrast to Korean or Japanese Confucianism, does not display factionalism; typical neo-Confucian themes, such as metaphysical thinking and efforts based on xin-xing (doctrine of heart-mind and human nature) are also not the main focus of Vietnamese Confucianism. Through a study of the geographic conditions of Vietnam and its ethnic demographics, we may be better be able to understand how "climate", broadly conceived, transformed and indigenized Vietnamese Confucianism. However, this question exceeds the scope of this paper, and I hope to return to the issue in the near future. 
(Research Collection on Vietnamese Confucianism). Taipei: Tai da chuban zhongxin.

Lunyu 論語 (The Analects). Translated by James Legge. Accessed September 30, 2019. https://ctext.org/analects.

Needham, Joseph. 1984. Science and Civilisation in China, vol.3. Translated by $\mathrm{Du}$ Weiyun et. al. Taipei: The Commercial Press.

Shangshu 合書 (The Book of Documents). Translated by James Legge. Accessed September 30, 2019. https://ctext.org/shang-shu.

Tran, Danh Lam. 2011. "Yuntai leiyu xu 芸臺類語序 (Vân đài loại ngữ tự, "Preface" of the Classified Discourses from Yun Stage). Yuntai leiyu 芸臺類語 (Vân đài loại ngữ, Classified Discourses from Yun Terrace) by Lê Quý Đôn.” In Yuenan Ruxue yanjiu congshu 越南儒學研究叢書 (Research Collection on Vietnamese Confucianism). Taipei: Tai da chuban zhongxin.

Tu, Weiming 杜維明. 2002. “Ruxue disanqi fazhan de qianjing 儒學第三期發展 的前景 (Perspectives on the Third Period of Confucianism). Xiandai jingshen yu rujia chuantong 現代精神與儒家傳統 (The Spirit of Modernity and Confucian tradition).”In Tu Weiming wenji 杜維明文集 (Tu Wei-ming's Collected Works), edited by Guo Qiyong 郭齊勇, and Zheng Wenlong 鄭文龍. Wuhan: Wuhan chuban she.

Watsuji, Tetsuro 和辻哲郎. 1962. “Fūdo 風土 (Climate)." In Watsuji Tetsuro zenshu 和辻哲郎全集 (Complete Works of Tetsuro Watsuji). Tokyo: Iwanami shoten.

Xue, Xuan 薛瑄. 1985. “Daolun 道論 (On the Dao).” In Congshu jicheng chubian 叢書集成初編 (Great Collection of Books). Beijing: Zhonghua shuju.

Yinfu jing 陰符經 (Classic of the Hidden Talisman). Translated by James Legge. Accessed September 30, 2019. https://ctext.org/yinfujing.

Yu, Xiangdong 于向東, and Tan Zhici 譚志詞. 2005. Yuenan: Gexin jincheng zhong rijian jueqi 越南: 革新進程中日漸崛起 (Vietnam: Rising by the Day in the Renovation Process). Hong Kong: City University of Hong Kong Press.

Yu, Xiangdong 于向東. 2000. Dongfang zhuming zhexuejia pingzhuan 東方 著名哲學家評傳 (Critical Biographies of Famous Eastern Philosophers). Jinan: Shandong renmin chuban she.

Zhongyong 中庸 (The Doctrine of the Mean). Translated by James Legge. Accessed September 30, 2019. https://ctext.org/liji/zhong-yong.

Zhu, Xi 朱喜. 1986. Zhuzi yulei 朱子語類 (Classified Dialogues of Master Zhu). Edited by Li Jingde 黎靖德. Beijing: Zhonghua shuju.

. 2001. Sishu huo wen 四書或問 (Questions and Answers on the Four Books). Edited by Huang Shen 黃珅. Shanghai: Shanghai guji chuban she. 